\title{
PERANCANGAN BUKU INFORMASI SITUS CANDI MAJAPAHIT DI TROWULAN
}

\section{Vita Octavian Anggraeni ${ }^{1)}$, Dian Handayani2)}

Program Studi Desain Komunikasi Visual, Fakultas Bahasa dan Seni, Universitas Indraprasta PGRI. Jalan Nangka No. 58 C, Tanjung Barat, Jakarta Selatan, 12530, Indonesia

diandkvunindra@gmail.com

\begin{abstract}
Abstrak
Situs Trowulan merupakan Ibu Kota Kerajaan Majapahit yang mulai di pugar oleh Pusat Penelitian Arkeologi sejak tahun 1970. Di wilayah yang memiliki luas 9 x $11 \mathrm{Km}$ ini ditemukan berbagai situs candi yang merupakan bukti kejayaan Kerajaan Majapahit yang masih bisa di nikmati keindahannya sampai sekarang. Situs ini merupakan warisan sejarah yang menjadi kebanggaan Indonesia khususnya Mojokerto. Penelitian ini dilakukan untuk merancang buku informasi yang menarik dan edukatif guna memberikan informasi tentang situs yang berada di Trowulan. Metode yang digunakan dalam penelitian adalah kualitatif yaitu dilakukan dengan studi literatur terkait objek candi yang berada di Trowulan, wawancara narasumber yang paham tentang kajian objek, dan observasi langsung ke Situs Trowulan yang berada di Mojokerto, Jawa Timur. Dari penelitian ini ditemukan data-data yang membuktikan bahwa Situs Trowulan Mojokerto Mojokerto merupakan Ibu Kota Kerajaan Majapahit. Tidak hanya data tertulis tentang candi-candi di Situs Trowulan, buku informasi juga membutuhkan data visual berupa foto guna mendeskripsikan candi-candi di Situs Trowulan dengan penerapan layout yang sesuai, sehingga menjadi satu kesatuan yang memudahkan pembaca untuk mendapatkan informasi.
\end{abstract}

Kata Kunci: Buku Informasi, Situs Trowulan, Majapahit.

\begin{abstract}
Trowulan site is the capital of the Majapahit, which has been restored by the Archaeological Research Center since 1970. The wide of the area is 9 x $11 \mathrm{~km}$. There is found vorius temple as a proof the glory of Majapahit that still can be enjoyed until now. This site is a historical heritage that be pride Indonesia, especially Mojokerto. This research was conducted to create an interesting and educative information book to provide information about sites in Trowulan. The method is qualitative, which is done by literature studies related to objects in Trowulan, interview with informants who understand object studies, and to Trowulan site in Mojokerto, East Java. From the data that found that proves Trowulan Mojokerto Site is the Capital of Majapahit Kingdom. In addition not only written data about temples on the Trowulan Site, but also information books require visual data in form of photos to describe temples on the Trowulan Site by applying appropriate layouts, so that it becomes a single unit that makes it easy for readers to get information.
\end{abstract}

Keywords: Information Book, Trowulan Site, Majapahit.

Correspondence author: Dian Handayani, diandkvunindra@gmail.com, Jakarta and Indonesia

This work is licensed under a CC-BY-NC 


\section{PENDAHULUAN}

Situs Trowulan merupakan situs yang diduga sebagai Ibu Kota Kerajaan Majapahit. Situs ini terletak di kota Mojokerto, Jawa Timur. Di tempat ini terdapat peninggalan sejarah berupa bangunan candi, patirtaan, dan bangunan yang di duga sebagai pintu gerbang Kerajaan Majapahit. Di daerah Trowulan ini ditemukan berbagai situs candi yang masih berdiri hingga sekarang.

Pemugaran Situs Trowulan ini dilakukan oleh Pusat Penelitian Arkeologi sejak tahun 1970. Penggalian juga pernah dilakukan oleh Universitas Gadjah Mada, sementara itu jurusan Arkeologi Universitas Indonesia menjadikan Trowulan sebagai tempat mendidik calon-calon arkeolog dari tahun 1987 hingga sekarang (Rochmani, 1995: 8). Seperti yang kita ketahui Majapahit merupakan salah satu kerajaan terbesar yang pernah ada di Indonesia. Didirikan pada tahun 1293 M oleh Raden Wijaya. Kerajaan ini cukup berjaya di masanya, menguasai berbagai daerah ternama. Arsitektur serta budayanya pun sudah cukup maju, sehingga menjadi sumber inspirasi berbagai bangunan setelah eranya. Setelah berabad-abad berjaya, kerajaan ini pun melemah dan akhirnya runtuh. Namun masih menyisakan bukti-bukti peninggalan berupa bangunan maupun benda-benda bersejarah. Penemuan Situs Trowulan oleh para peneliti ini seperti memberikan kesempatan untuk menikmati serta mengkaji peninggalan sejarah dari Kerajaan Majapahit.

Maka dari itu dibuatnya media buku Informasi sebagai wadah untuk menggambarkan dan memberi informasi kepada masyarakat tentang situs ini. Buku informasi berisi foto-foto keadaan di lapangan serta berisi informasi tentang keberadaan dan sejarahnya. Kelebihan media ini adalah dapat digunakan untuk jangka panjang sebagai literatur maupun referensi bagi peneliti selanjutnya. Masyarakat awam pun juga bisa menikmatinya sebagai penambah wawasan tentang salah satu bukti sejarah di Indonesia berupa Situs Majapahit di Trowulan. Buku informasi juga dapat di desain dan di layout semenarik mungkin agar tidak membosankan dan menambah minat pembaca tentang materi situs sejarah yang ada di Trowulan ini.

\section{METODE PENELITIAN}

Metode penelitian yang digunakan dalam penelitian ini adalah jenis penelitian kualitatif yaitu mengumpulkan data melalui wawancara, catatan lapangan, dokumen resmi dengan menggambarkan realita. Creswell (dalam Somantri, 2005: 58) mengemukakan bahwa penelitian kualitatif lebih mengutamakan logika dari data yang dilahirkan dalam perjumpaan dengan informan di lapangan atau data yang ditemukan sehingga informasi membuktikan teori yang akan menjelaskan fenomena sosial.

Penelitian dilakukan melalui beberapa metode yaitu:

1. Studi Pustaka

Dari data yang didapat, peneliti menggunakan jenis penelitian kualitatif yaitu studi kepustakaan metode pengumpulan data yang menggunakan referensi buku, jurnal dan website yang berkaitan pada materi yang mendukung penelitian ini.

2. Observasi

Peneliti juga melakukan observasi guna menambah data yang sudah diperoleh. Hal ini dilakukan untuk peneliti agar tidak hanya membayangkan keadaan situs melalui literatur, sehingga mengetahui keadaan sebenarnya yang berada di lokasi. Observasi dilakukan pada bulan Juli 2018. Observasi ini dilakukan dengan mengunjungi candi-candi yang berada di Situs Trowulan, Mojokerto. Seperti Candi Wringin Lawang, Candi Bajang Ratu, Candi Tikus dan Candi Brahu.

3. Wawancara

Wawancara dilakukan oleh peneliti kepada narasumber yang kepakarannya terkait dengan objek penelitian. Wawancara tersebut dilakukan pada bulan Juni 2018 dengan Prof. Dr. Agus Aris Munandar, M.Hum. Sebagai ahli di bidang arkeologi. Menurut beliau Trowulan merupakan kota besar pada masanya. Banyak bukti yang mendeskripsikan bahwa Trowulan merupakan Ibu Kota Majapahit. Beliau menceritakan asal mula Trowulan beserta peninggalan-peninggalannya dengan cerita yang runtut menurut sejarah Majapahit yang 
beliau ketahui. Menurut beliau Trowulan merupakan jejak kota kerajaan besar karena bukti peninggalan yang ditemukan merupakan satu kompleks yang sekarang disebut dengan Situs Trowulan.

\section{HASIL DAN PEMBAHASAN \\ Buku Informasi}

Buku informasi merupakan buku yang berisi kumpulan data baik berupa tulisan, tabel, gambar maupun foto. Menurut Rustan (2009: 122), buku merupakan salah satu media untuk menyampaikan informasi baik berupa cerita, pengetahuan, laporan, dan lain-lain.

Buku informasi relatif cocok digunakan untuk pengaplikasian media yang berisi tentang situs sejarah. Dengan buku informasi data dapat di cantumkan secara menyeluruh dengan tambahan data visual berupa foto objek yang dibahas maupun ilustrasi. Buku dapat di desain semenarik mungkin dari cover sampai ke layout isi, guna menarik minat pembaca agar tidak mudah bosan dan dapat menyerap materi sebanyak - banyaknya dalam buku informasi. Foto yang di ambil pada objek dengan menggunakan berbagai teknik fotografi untuk menonjolkan nilai estetik dalam bangunan candi di Situs Trowulan ini. Layout isi juga harus diperhatikan agar tidak menimbulkan kesan membingungkan.

Segmentasi buku informasi ini antara usia 21-30 tahun karna di umur tersebut cenderung memiliki ketertarikan sejarah dan situs - situs di Indonesia, baik itu untuk referensi wisata ataupun keperluan di pendidikannya. Memiliki ketertarikan dengan fotografi dan nilai-nilai dari objek peninggalan sejarah. Gemar membaca buku-buku informasi sebagai referensi maupun koleksi.

\section{Latar Belakang Sejarah Asal-usul Trowulan}

Pemugaran Situs Trowulan ini dilakukan oleh Pusat Penelitian Arkeologi sejak tahun 1970. Penggalian juga pernah dilakukan oleh Universitas Gadjah Mada, sementara itu jurusan Arkeologi Universitas Indonesia menjadikan Trowulan sebagai tempat mendidik dan melatih calon-calon arkeolog dari tahun 1987 hingga sekarang (Rochmani, 1995: 8). Kawasan Trowulan menunjukkan adanya pertukaran budaya yang penting dari peradaban besar pada masa lalu. Pada area tersebut di temukan berbagai peninggalan Kerajaan Majapahit seperti candi-candi, bangunan, kolam, gapura, dan saluran-saluran air yang mengidentifikasikan sebuah kota yang cukup maju pada masa itu (Rangkuti, 2006: 15).

Dalam buku Nagarakertagama terdapat rincian tentang gambaran Kota Majapahit. Ibu Kota Kerajaan mempunyai tembok keliling dari batu merah yang tebal dan tinggi. Sesuai dengan keadaan berbagai situs di Trowulan yang masih berdiri hingga sekarang.

Trowulan merupakan sebuah tempat yang dikenal sebagai kawasan bersejarah, dimana situs-situs peninggalan kerajaan besar tanah Jawa ditemukan. Situs-situs itu tidak hanya satu bangunan, melainkan satu kawasan, terdiri dari berbagai bangunan candi, artefak-artefak, dan arca-arca yang dipengaruhi agama Hindu dan Buddha. Dua agama besar di Jawa pada masa itu, yang juga menjadi agama resmi kerajaan Majapahit. Seperti yang kita ketahui Majapahit merupakan salah satu kerajaan terbesar yang pernah ada di Indonesia.

\section{Kerajaan Majapahit}

Didirikan pada tahun 1293 M oleh Raden Wijaya. Ia mengangkat dirinya menjadi Raja Majapahit pertama dengan gelar Raja Kertarejasa. Tempat ia bermukim di dirikan keraton yang letaknya sangat strategis untuk mengawasi kerajaan Kediri. Kerajaan ini cukup berjaya di masanya, menguasai berbagai daerah-daerah ternama.

Kerajaan Majapahit berkembang selama 200 tahun, meninggalkan berbagai benda arkeologi yang bersifat monumental. Arsitektur serta budayanya pun sudah cukup maju, sehingga menjadi sumber inspirasi berbagai bangunan setelah eranya.

Berkembang sekitar 200 tahun, dan diperkirakan runtuh antara tahun $1519-1525 \mathrm{M}$ yang menghasilkan berbagai bukti peninggalan berupa kebudayaan, bangunan maupun benda bersejarah. 


\section{Letak dan Lingkungan}

Situs Trowulan termasuk dalam kecamatan Trowulan dan Kecamatan Sooko, Kabupaten Mojokerto, Provinsi Jawa Timur. Situs ini memiliki luas 9 x $11 \mathrm{~km}$ yang terletak sekitar $55 \mathrm{~km}$ di arah barat daya dari Kota Surabaya. Situs ini berada di antara pemukiman warga, belum terlalu dikenal masyarakat luas, sehingga keberadaan Situs Trowulan ini hanya di ketahui oleh sebagian orang atau orang-orang tertentu yang menyukai tentang sejarah kerajaan seperti Majapahit. Di Situs Trowulan Majapahit ini terdapat beberapa bangunan peninggalan masa Kerajaan Majapahit, yang masih bisa dilihat dan berdiri dengan kokoh hingga sekarang.

\section{Candi - Candi di Situs Trowulan}

\section{Candi Wringin Lawang}

Lokasinya berada di Dukuh Wringin Lawang, Desa Jatipasar, Kecamatan Trowulan. Terlihat seperti Gapura yang konon merupakan pintu gerbang dari kerajaan Majapahit. Di situs ini dulunya tumbuh sepasang pohon beringin dan karena itulah disebut "Wringin Lawang". Dalam konsep hindu memiliki makna simbolis, bahwa di dunia manusia hanya memiliki dua pilihan dalam hidupnya, yakni baik dan buruk. Candi Wringin Lawang diperkirakan menjadi salah satu pintu perbatasan menuju pusat kota Majapahit.

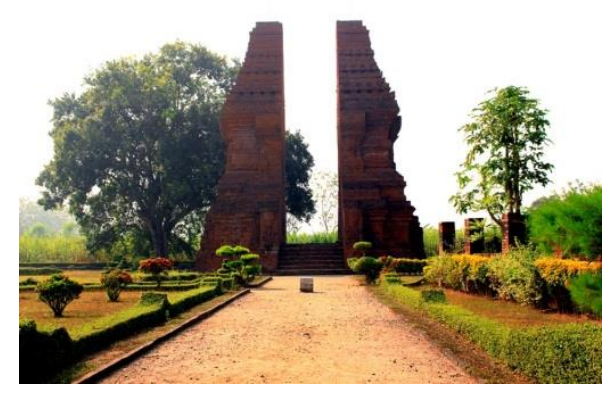

Gambar 1 Candi Wingin Lawang Sumber: Dokumentasi Pribadi

Bangunan agung ini terbuat dari bata merah dan dalam keadaan polos tanpa hiasan. Bangunan Gapura Wringin Lawang yang tersusun dari susunan bata kini menjadi gapura di Jawa Timur. Sebuah ciri arsitektur yang bertahan berabad - abad lamanya. Gapura Wringin Lawang menempati areal tanah seluas $616 \mathrm{~m}^{2}$. Bentuk gapura adalah candi bentar dengan denah empat segi panjang berukuran panjang $13 \mathrm{~m}$, lebar 11,5 m, dan tinggi 15,50 m (Rochmani, 1995: 38).

Gerbang Wringin Lawang tersebut lazim disebut "candi bentar" (candi terbelah dua). Akan tetapi gerbang ini bukanlah candi melainkan gapura yang memang serupa benar dengan candi, akan tetapi seolah-olah dibelah menjadi dua bagian yang sama, dari atas ke bawah sama bentuk dan kemudian diletakkan renggang bagian atap tidak tertutup. Gaya arsitektur seperti ini sering di temui pada era Majapahit dan kini banyak ditemukan dalam arsitektur bangunan maupun candi yang ada di Bali.

Menurut pengelola, candi tersebut masih aktif digunakan masyarakat sekitar yang menganut agama Hindu ataupun Kejawen. Bahkan tak jarang orang hindu dari bali pun mengunjungi candi ini untuk melakukan sembahyang atau menaruh sesaji dan membakar kemenyan di antara gerbang majapahit ini.

\section{Candi Bajang Ratu}

Candi Bajang Ratu adalah sebuah candi peninggalan Majapahit yang berada sejauh $2 \mathrm{~km}$ dari pusat kanal perairan Majapahit, berada di Dusun Kraton, Desa Temon. Candi Bajang Ratu 
pernah dipugar dalam rangka pelestarian dan diresmikan pada tahun 1992 oleh Dirjen Kebudayaan Departemen Pendidikan dan Kebudayaan Republik Indonesia.

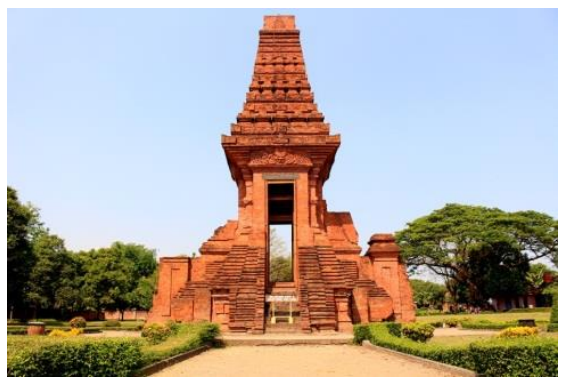

Gambar 2 Candi Bajang Ratu

Sumber: Dokumentasi Pribadi

Nama Bajang Ratu sendiri diambil dari Bahasa Jawa yaitu bujang (bajang). Ketika penobatan Raja Jayanegara, beliau masih muda maka dari itu sering disebut Bajang Ratu. Candi Bajang Ratu merupakan bangunan candi berbentuk gapura dengan atap, yaitu gapura kedua yang biasa terdapat pada bangunan besar era Majapahit. Candi ini juga memiliki nama lain, yakni Kori Agung yang berarti pintu gerbang yang megah sebagai pintu gerbang kedua karena perbedaannya dengan Candi Wringin Lawang yang tanpa atap sebagai pintu gerbang pertama.

Candi Bajang Ratu pada mulanya memiliki fungsi sebagai bangunan suci untuk memperingati wafatnya Raja Jayanegara. Namun, sebenarnya sebelum wafatnya Raja Jayanegara candi ini dipergunakan sebagai pintu belakang kerajaan. Dugaan ini didukung adanya relief Sri Tanjung dan sayap gapura yang melambangkan pelepasan dan sampai sekarang di daerah Trowulan, sudah menjadi suatu kebudayaan jika berziarah diharuskan lewat pintu belakang.

\section{Candi Tikus}

Candi Tikus berada di Dusun Dinuk, Desa Temon, Kecamatan Trowulan, Kabupaten Mojokerto, letaknya sekitar $500 \mathrm{~m}$ dari Candi Bajang Ratu. Candi Tikus pada dasarnya lebih rendah dari permukaan tanah sekitarnya, yaitu pada kedalaman 3,5 m dengan ukuran 22,50 x 22,50 m (Rochmani, 1995:13).

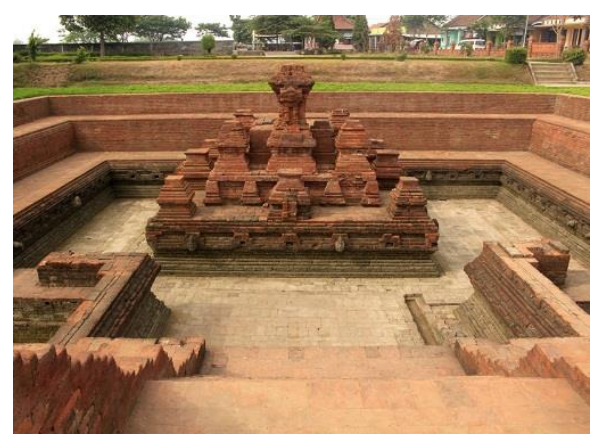

Gambar 3 Candi Tikus

Sumber: Dokumentasi Pribadi

Candi tersebut dikenal dengan nama Candi tikus karena pada tahun 1914 di daerah tersebut sedang terjadi hama tikus yang menyebabkan gagal panen. Setelah sepakat para warga pun membasminya dengan penggalian sarang-sarang tikus di lahan persawahan, setelah digali ditemukanlah bangunan yang sekarang disebut dengan Candi Tikus.

Saat kemarau candi ini terlihat seperti candi di Trowulan pada umumnya, tetapi saat penghujan terlihatlah bangunan petirtaan karena bangunan candi dilengkapi oleh tangga masuk untuk turun ke kolam, pancuran-pancuran di setiap sisinya dan bangunan inti di tengah kolam. 


\section{Candi Brahu}

Candi Brahu berdiri di permukaan tanah datar pada ketinggian 32,79 m diatas permukaan laut. Sebagaimana umumnya candi di Situs Trowulan yang terbuat dari bata merah, denahnya berbentuk segi empat dengan ukuran 18 x 22,5 m dengan tinggi candi $22 \mathrm{~m}$ (Rochmani, 1995: 22).

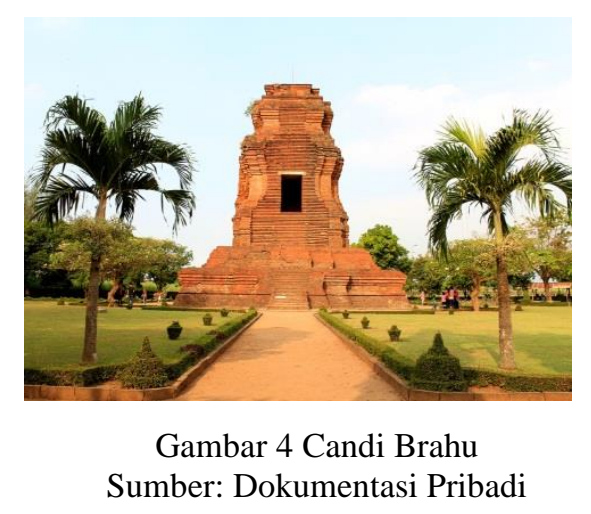

Candi ini terletak di Dukuh Jambumente, Desa Bejijong, Kecamatan Trowulan. Candi tersebut sudah tidak dapat untuk dinaiki oleh pengunjung karena batu bata yang sudah rapuh, sehingga dikhawatirkan runtuh dan merubah bentuk candi. Candi agama Budha ini diperkirakan lebih tua dari candi-candi lain di Situs Trowulan. Nama Brahu berasar dari kata waharu atau warahu yang merupakan nama bangunan suci dalam prasasti tembaga Alasanta yang ditemukan dalam lokasi yang berdekatan. Prasasti tersebut dikeluarkan oleh Mpu Sindok pada tahun 861 saka atau tahun 939. Saat pembongkaran Candi Brahu ditemukannya sisa-sisa arang. Setelah dianalisis oleh Pusat Penelitian Badan Tenaga Atom Nasional di Yogyakarta, arang tersebut berasal dari abad 1410 sampai 1646 (Rochmani, 1995: 37)

\section{Candi Gentong}

Terletak di desa Jambumente kecamatan Trowulan yang letaknya berdekatan dengan candi Brahu. Candi ini sudah tidak berbentuk utuh melainkan tinggal reruntuhannya saja. Bangunan reruntuhan candi ini mulai dipugar tahun 1995, dengan perkiraan berbentuk bujursangkar dengan ukuran kira-kira 14,25 x 14,25 m dengan tinggi 2,45 m dan tebal dinding 1,9 m (Rochmani, 1995: 40)

Didasari konsep tata ruang dan di dukung oleh temuan artefaktual yang bersifat agama Budha, Candi Gentong disimpulkan merupakan Mandala Stupa dimana bangunan pusat dikelilingi oleh ruangan-ruangan lain yang lebih kecil, namun secara keseluruhan bentuk asli candi masih belum diketahui karena reruntuhan yang merata dan tidak berbentuk sehingga membuat kesulitan para arkeolog untuk menelitinya.

\section{Candi Menakjinggo}

Reruntuhan candi ini mulai dipugar tahun 1977-1985 yang menghasilkan bentuk denah berukuran 24,30 x 27,80 m. Berbahan dasar Batu bata dan Batu Andesit. Candi Menakjinggo terletak di Dusun Unggah-unggahan, Trowulan yang disebut juga sebagai Sanggar Pamelengan. Pada tahun 1977 dilakukannya penggalian dan ditemukan tiga lapis pondasi dalam candi ini meski hanya tinggal reruntuhannya saja. Dalam Candi Menakjinggo ditemukan relief pada batunya berupa aktivitas masyarakat Majapahit, binatang, struktur bangunan dan sebagainya, juga ditemukannya 2 arca yang disimpan di Pusat Informasi Majapahit Trowulan (Munandar, 2015: 105).

\section{Candi Kedaton}

Berdenah empat persegi panjang dengan ukuran 9,5 x 12,6 m dan tinggi yang masih tersisa 1,58 m. Candi ini terletak di Situs Sumur Upas, Trowulan. Dalam situs ini terdapat balok 
batu berangka tahun 1297 saka (1375). Candi Kedaton bukanlah bangunan suci untuk pemujaan, sebab tidak ditemukan bukti-bukti yang menunjukkan bahwa bangunan tersebut merupakan tempat sakral (Munandar, 2015: 23).

\section{Proses Perancangan Buku Informasi}

\section{Analisa Khalayak}

Penyampaian informasi diperlukannya suatu media yang dapat menyalurkan kepada khalayak. Banyak media yang dapat digunakan, namun perlu adanya pemilihan media yang sesuai dengan jenis informasi yang disampaikan. Dalam menyampaikan informasi seperti sejarah suatu situs, diperlukannya media yang mencantumkan banyak informasi dan gambar berupa ilustrasi ataupun foto guna memberi gambaran yang lengkap dan jelas kepada khalayak. Desain media pun perlu dikreasikan agar lebih menarik minat khalayak.

\section{Positioning}

Positioning dari perancangan buku informasi ini adalah untuk menginformasikan dan mengenalkan kepada khalayak bahwa Situs Trowulan ini merupakan jejak ibu kota dari Kerajaan Majapahit. Jadi masyarakat mengetahui bahwa Kerajaan Majapahit ini benar adanya karena terdapat banyak bukti peninggalan Kerajaan Majapahit yang tersisa di Situs Trowulan, Mojokerto.

\section{Konsep Visual}

Untuk memperoleh segmentasi khalayak yang sesuai dengan masyarakat maka dibutuhkan pemilihan foto, ilustrasi, tipografi, layout, warna, materi buku yang akan digunakan dan media promosi yang diperlukan.

Foto dipilih berdasarkan jelasnya objek yang akan dideskripsikan. Tentunya foto yang paling menarik dipilih dari berbagai sudut objek yang telah dipotret sebelumnya. Foto yang menarik akan menambah nilai dari buku informasi.

Ilustrasi yang dipilih dalam perancangan buku informasi ini adalah ilustrasi dari Candi Brahu dan Candi Wringin Lawang sebagai bagian dari desain cover. Model ilustrasi menggunakan teknik fotografi karena terdiri dari berbagai dokumentasi foto yang menjadi penjelasan dari materi buku.

\section{Tipografi}

\section{Situs Majapahit Tramulan}

Tipografi yang digunakan dalam buku informasi ini adalah font Dancing Script sebagai text judul di cover depan buku informasi. Jenis font ini berbentuk melekuk dan termasuk font sambung yang indah dilihat dan menarik minat khalayak untuk membacanya.

\section{Situs Majapahit Trowulan}

Kemudian font Cabrito Regular untuk bagian isi buku. Font ini dipilih karena karakternya yang ringan dan mudah dibaca, karena materi buku bertema sejarah ini terdapat banyak text, maka font ini lebih sesuai untuk pembaca agar tidak mudah bosan.

\section{Tata Letak (Layout)}

Tata letak dalam buku informasi ini umumnya menggunakan $60 \%$ foto dan $40 \%$ text untuk menghindari kebosanan yang biasanya dialami pembaca saat membaca buku yang penuh dengan text. Kemudian terdapat foto yang memenuhi 2 halaman (spread) sebagai variasi layout buku agar tidak monoton. 
Memfokuskan pola keterbacaan komposisi layout dengan tidak menambah atau menggunakan banyak content membuat pembaca lebih mudah menyerap materi buku. Dalam beberapa halaman menggunakan jenis Jumble Layout yaitu penyajian media informasi dengan beberapa gambar dan text yang disusun secara teratur (Anto dkk., 2017: 96).

\section{Warna}

Warna yang digunakan adalah warna cokelat untuk background. Turunan warna cokelat tua sampai cokelat muda di gunakan dalam buku informasi ini untuk menyesuaikan warna isi buku dan cover-nya.

\section{Judul Buku}

Judul Buku yang dipilih adalah Situs Majapahit Trowulan karena akan lebih membahas peninggalan Kerajaan Majapahit yang masih ada di Trowulan Mojoketo. Kata Trowulan yang merujuk pada daerah dimana terdapat berbagai situsnya guna memperkenalkan daerah Trowulan bagi pembaca agar mudah diingat saat membahas tentang Kerajaan Majapahit.

\section{Desain Buku}

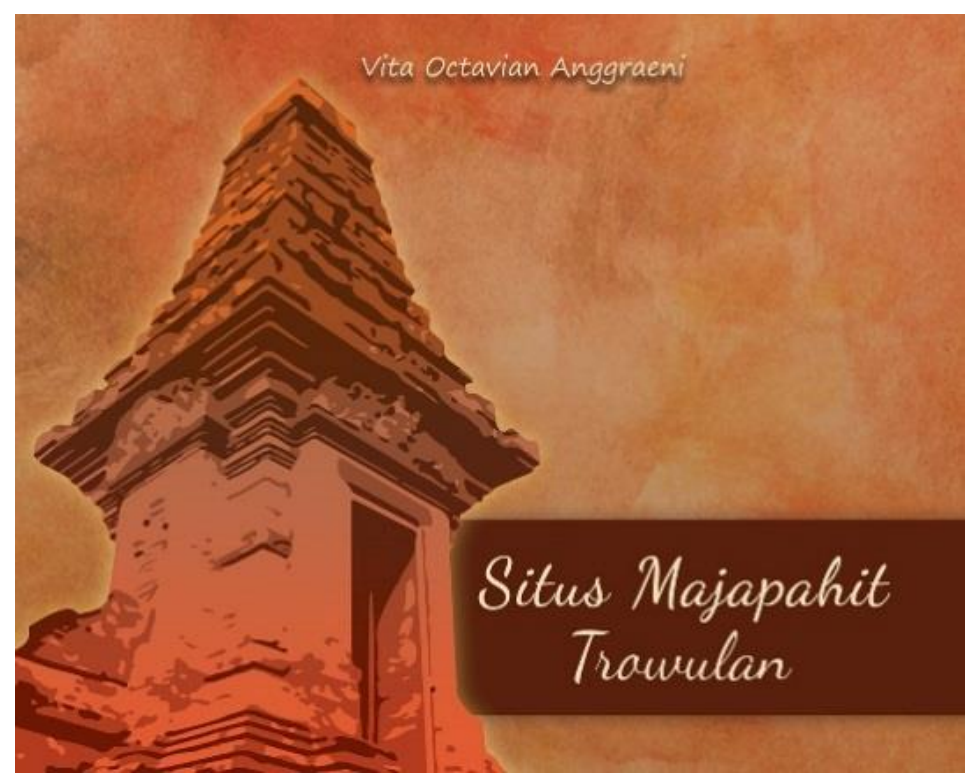

Cover depan dibuat dengan warna dasar cokelat yang menimbulkan kesan sejarah sesuai dengan objek yang diambil. Dikombinasikan dengan ilustrasi salah satu candi yaitu Candi Bajang Ratu yang berada di Situs Trowulan. Background cover juga ditambahkan kesan vintage yang ditunjukkan dari texture background agar menambah karakteristik cover buku informasi ini. 


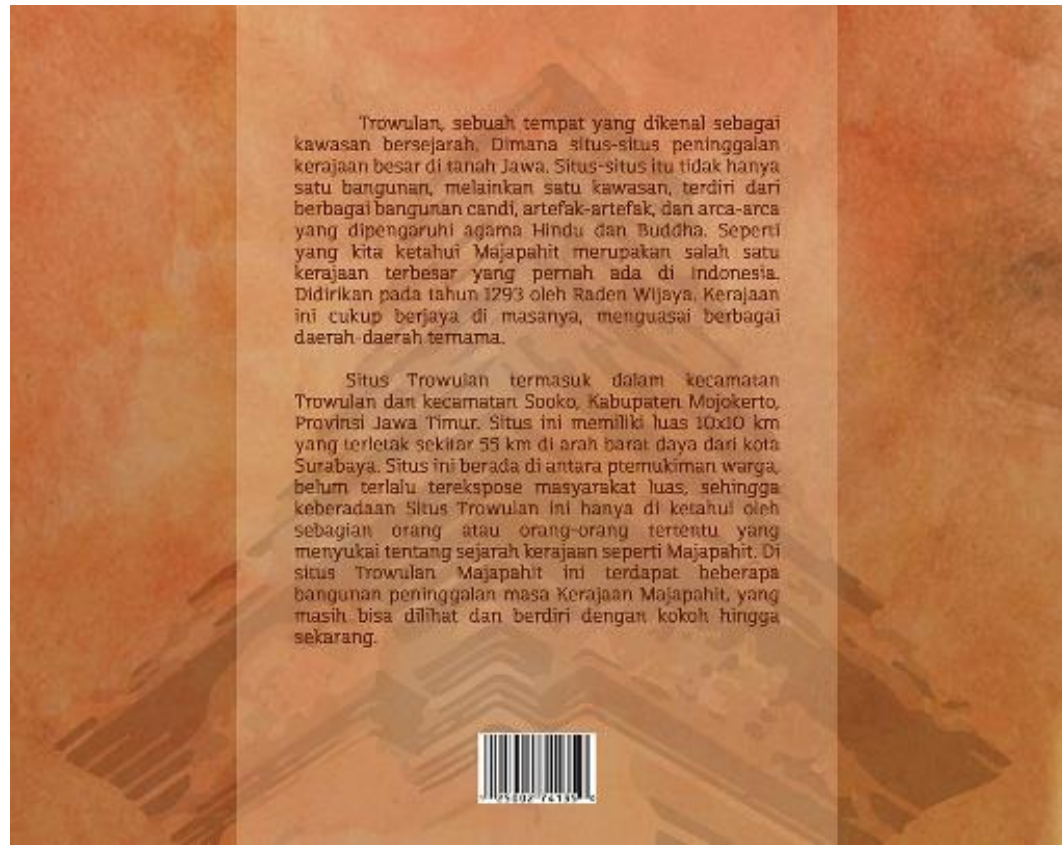

Dalam cover belakang terdapat ringkasan isi buku dengan background atap candi Brahu yang disamarkan agar tidak mengganggu keterbacaan tulisan.

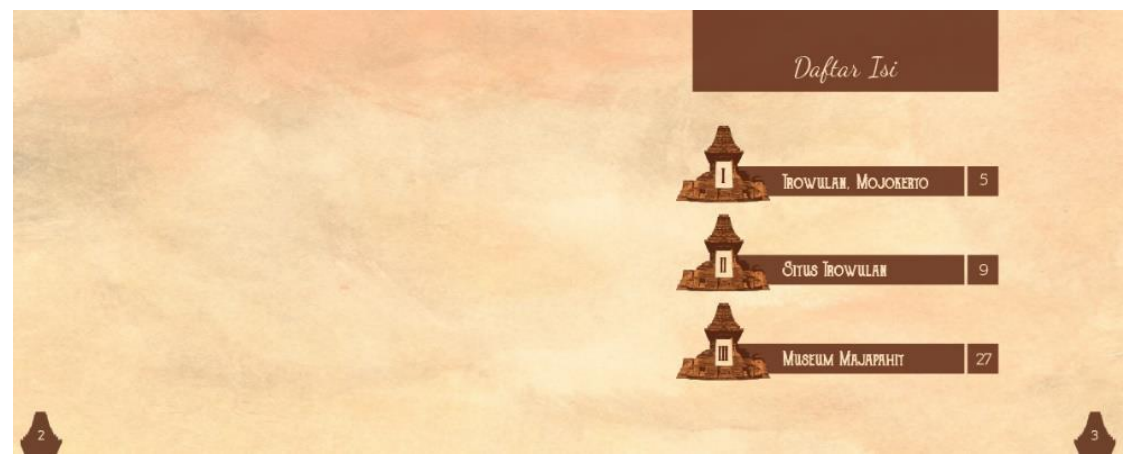

Desain pada halaman daftar isi menganut tema dari cover, terdapat ilustrasi dari Candi Brahu dan bentuk persegi panjang berwarna cokelat tua sebagai alas atau dasar untuk judul-judul bab dalam isi buku. Bab terdiri dari 3 judul untuk memudahkan pemisahan dalam pembahasan Situs Trowulan.
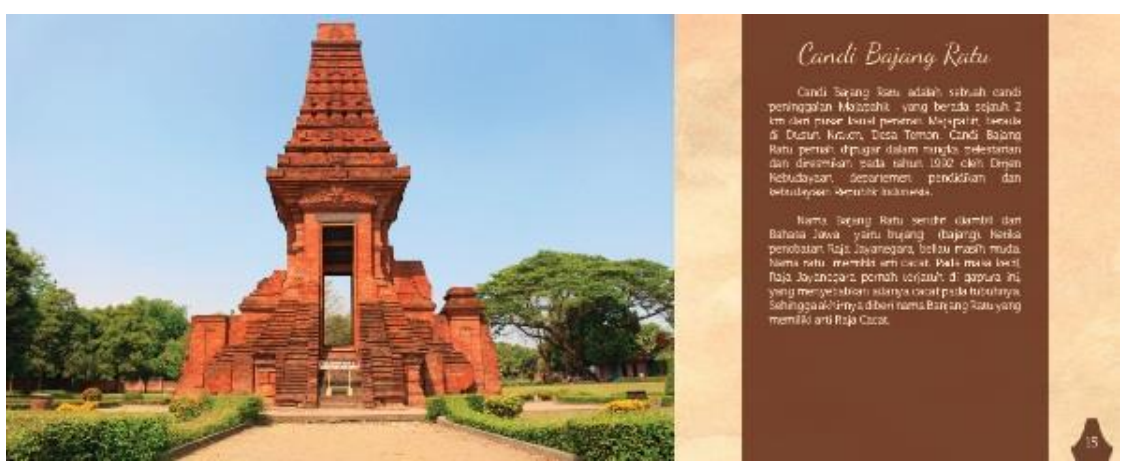
Layout isi buku menggunakan perbandingan foto $60 \%$ dan tulisan $40 \%$. Foto diletakkan melewati batas halaman, dan text diletakkan di atas bidang berwarna cokelat tua.

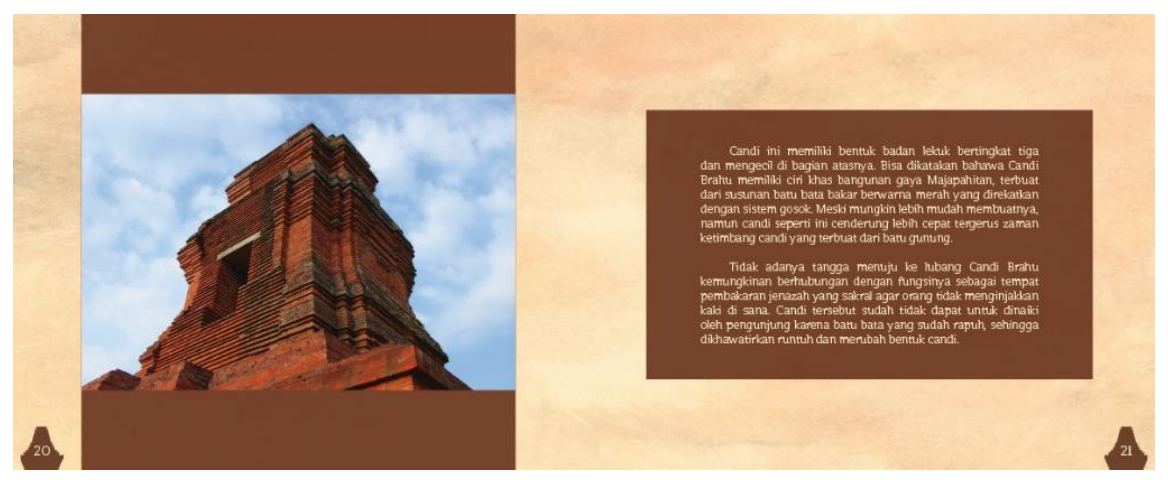

Layout per halaman pun divariasi agar tidak menimbulkan kejenuhan saat membaca. Letak nomor halaman diletakkan di pojok dengan alas bentuk atas candi yang berwarna cokelat tua juga. Background isi dibuat senada dengan cover sehingga terlihat selaras.

\section{SIMPULAN}

Situs Trowulan yang berada di Kota Mojokerto merupakan Situs yang diduga sebagai Ibu Kota dari Kerajaan Majapahit dengan segala buktinya. Situs ini memberikan gambaran nyata adanya kerajaan besar di zaman dahulu yang telah maju peradabannya. Ditunjukkan dengan banyaknya peninggalan bangunan beserta jejak tinggal masyarakatnya.

Penelitian ini guna memberi referensi berupa buku informasi bagi peneliti lain maupun masyarakat awam yang tertarik pada Situs Trowulan atau peninggalan Kerajaan Majapahit. Karena di dalamnya terdapat berbagai informasi terkait situs ini beserta foto candi-candi yang dapat memberi sebuah gambaran tentang Ibu Kota Majapahit. Diharapkan penelitian ini menjadi motivasi bagi pemerintah untuk tetap memperhatikan pengelolaan Situs Trowulan di Mojokerto agar dapat dinikmati oleh generasi yang akan dating, sehingga mereka juga dapat melihat situssitus peninggalan Kerajaan Majapahit.

\section{DAFTAR PUSTAKA}

Anto, P., Andrijanto, M. S., \& Akbar, T. (2017). Perancangan buku pedoman umum ejaan bahasa Indonesia sebagai media pembelajaran di sekolah. Jurnal Desain, 4(02), 92-99.

Munandar, A. A. (2015). Keistimewaan candi-candi zaman Majapahit. Jakarta: Wedatama Widya Sastra.

Rochmani, K. S. (1995). Upaya pelestarian situs kota Kerajaan Majapahit di Trowulan, Mojokerto, Jawa Timur.

Rangkuti, N. (2006). Majapahit Trowulan. Jakarta: Museum Nasional.

Rustan, S. (2009). Layout: Dasar \& penerapannya. Jakarta: Gramedia.

Somantri, G. R. (2005). Memahami metode kualitatif. Makara, Sosial Humaniora, 9(2), 57-65. 